\title{
Nový sídlištní soubor štípané industrie starší doby bronzové z lokality Tvrdonice - Pole od Týnecka.
}

\section{New assemblage of Early Bronze Age chipped stone industry from a settlement site at Trrdonice - Pole od Týnecka}

\section{Ludmila Kaňáková / František Trampota}

\begin{abstract}
Abstrakt
Záchranný výzkum Regionálního muzea v Mikulově, vedený roku 2012 F. Trampotou, byl dosud jen krátce publikován (Trampota 2013, 192). Článek přináší výsledky analýzy středně velkého souboru štípané industrie (dále jen Šl) z únětických a ojediněle věteřovských sídlištních objektů a kulturní vrstvy s nálezy únětické i věteřovské keramiky. Soubor je z hlediska starší doby bronzové kompaktní, únětickému osídlení nepředcházelo starší osídlení, takže je vyloučena intruze. Z pozdějších období byla zjištěna jen chata a jeden další objekt, které spadají do laténu C. Soubor se některými svými projevy vymyká dosavadnímu poznání sídlištního inventáře štípané industrie starší doby bronzové na jižní Moravě.
\end{abstract}

\section{Klíčová slova}

starší doba bronzová, únětická kultura, Morava, štípaná industrie, sídliště

\begin{abstract}
The rescue excavation conducted by F. Trampota from the Regional Museum in Mikulov in 2012 was so far published only in brief (Trampota 2013, 192). The article presents the results of the analysis of a medium-sized assemblage of chipped stone industry from settlement features of Únětice Culture and sporadically also Věteřov Culture, and from the occupation layer containing finds of Únětice and Věteřov pottery. The assemblage is compact as regards the Early Bronze Age; the Únětice settlement was not preceded by any older occupation, so that intrusion is excluded. From later periods only a hut and a second feature were identified, which fall within La Tène $C$. The assemblage with some of its characteristics deviates from the present knowledge of Early Bronze Age chipped stone industry from settlement sites in South Moravia.
\end{abstract}

\section{Keywords}

Early Bronze Age, Únětice culture, Moravia, chipped stone industry, settlement

Tento článek vznikl za podpory grantového projektu specifického výzkumu MUNI/A/1130/2014 Archeologická terénní prospekce, exkavace, dokumentace a muzejní prezentace IV. 


\section{Úvod}

Záchranný výzkum před stavbou plynovodu zjistil sídliště ze starší doby bronzové již dříve zachycené na sousedních parcelách (Unger 1973; 1975). Nově zkoumaná část sídliště se nachází na pravém břehu potoka Svodnice. Sídliště bylo založeno na písečné duně, přičemž zkoumaný úsek byl veden na okraji duny a v přechodu do nivy potoka. Geologické podloží větší části lokality je tvořeno vápnitými navátými písky, ojediněle jíly a akumulačními sedimenty potoka Svodnice. Geomorfologicky se jedná o oblast Vídeňské pánve.

Lokalita Pole od Týnecka se nachází západně od Tvrdonic v úhlu mezi pravým břehem potoka Svodnice a pravou stranou okresní silnice spojující Tvrdonice s nádražím Hrušky (okolí bodu $48^{\circ} 46^{`} 19.8^{\prime \prime} \mathrm{N}, 16^{\circ} 57^{\circ} 57.3$ “E). Polohu lokality přibližuje Obr. 1.

Archeologická situace starší doby bronzové byla tvořena kromě zásobních objektů a kůlových jamek i cca 20 cm mocnou kulturní vrstvou, která obsahovala únětickou i věteřovskou keramiku. Tato vrstva označená jako obj. 501 je prostorově omezená a tvoří přímý stratigrafický vztah pouze s několika kůlovými jamkami.

Mimo tuto vrstvu pocházejí archeologické artefakty především z kónických zásobnicových jam charakteristických pro starší dobu bronzovou. Z hlediska množství bylo nejvíce artefaktů nalezeno v kumulaci zásobních jam označených jako obj. 502 až 506 a 508, zatímco druhá kumulace objektů (obj. 509, 511, 512, 515/166, 517, $522,529)$ byla na nálezy výrazně chudší. Z toho objekty 509, 515/166, 522 a 529 se nacházely v dílčí, či úplné superpozici pod laténskými objekty, případně i inženýrskými sítěmi (Obr. 2).

V jihozápadní části skryté plochy byly po skrývce identifikovány archeologické objekty, zatímco v severovýchodní části byla zjištěna vrstva se smíšenými nálezy ze starší doby bronzové i laténu. Tato oblast byla zkoumána pomocí sondáží, v podloží zde byly archeologické objekty zjištěny o výrazně menší hustotě i menších rozměrech.

Z hlediska keramické typologie odpovídá věteřovské keramice objekt 520 (Obr. 3) a určitý podíl z kulturní vrstvy (obj. 501), keramika z dalších objektů je únětická. Dosavadní studium keramiky z této lokality je omezeno na materiálové analýzy inkrustace únětických nádob (V̌sianský et al. 2014).

Soubor štípané industrie zahrnuje 33 artefaktů ${ }^{1}$, morfologicky i surovinově odpovídajících našim dosavadním poznatkům o industrii starší doby bronzové. Ze staršího výzkumu J. Ungera není žádná štípaná industrie zmiňována a není doložena ani v muzejním fondu. Proto je nálezový soubor z výzkumu roku 2012 hodnocen samostatně.

Soubor z Tvrdonic se řadí k sídlištním souborům spíše drobnějším, v porovnání například se sídlištními soubory Blučina - Padělky (49 ks; Kaňáková 2013, 44-49 katalog), Šatov - Nad tokem Danýže (50 ks; Hladíková 2004, 65-73), Hrádek I - Vinohrad (51 ks; Kaňáková 2013, 183-188 katalog), nebo Mikulov - Kamenné (52 ks, Kaňáková 2013, 226-227 katalog) aj.

Charakterem sídlištních a hrobových nálezů štípané industrie starší doby bronzové se rovněž zabývá práce J. Kopacze (Kopacz - Šebela 2006), v jejímž obsáhlém katalogu je také možné najít srovnatelné soubory, ačkoli metodologický přístup je odlišný².

Cílem tohoto příspěvku není nové širší pojednání o ŠI v tomto období, nebot dosavadní nálezy byly podrobně komparovány, a nový soubor s ohledem na svůj rozsah nijak zásadně do diskuse nezasahuje, spíše rozšiřuje kolekci

- Obr. 1. Poloha lokality.

- Fig. 1. Location of the site. 


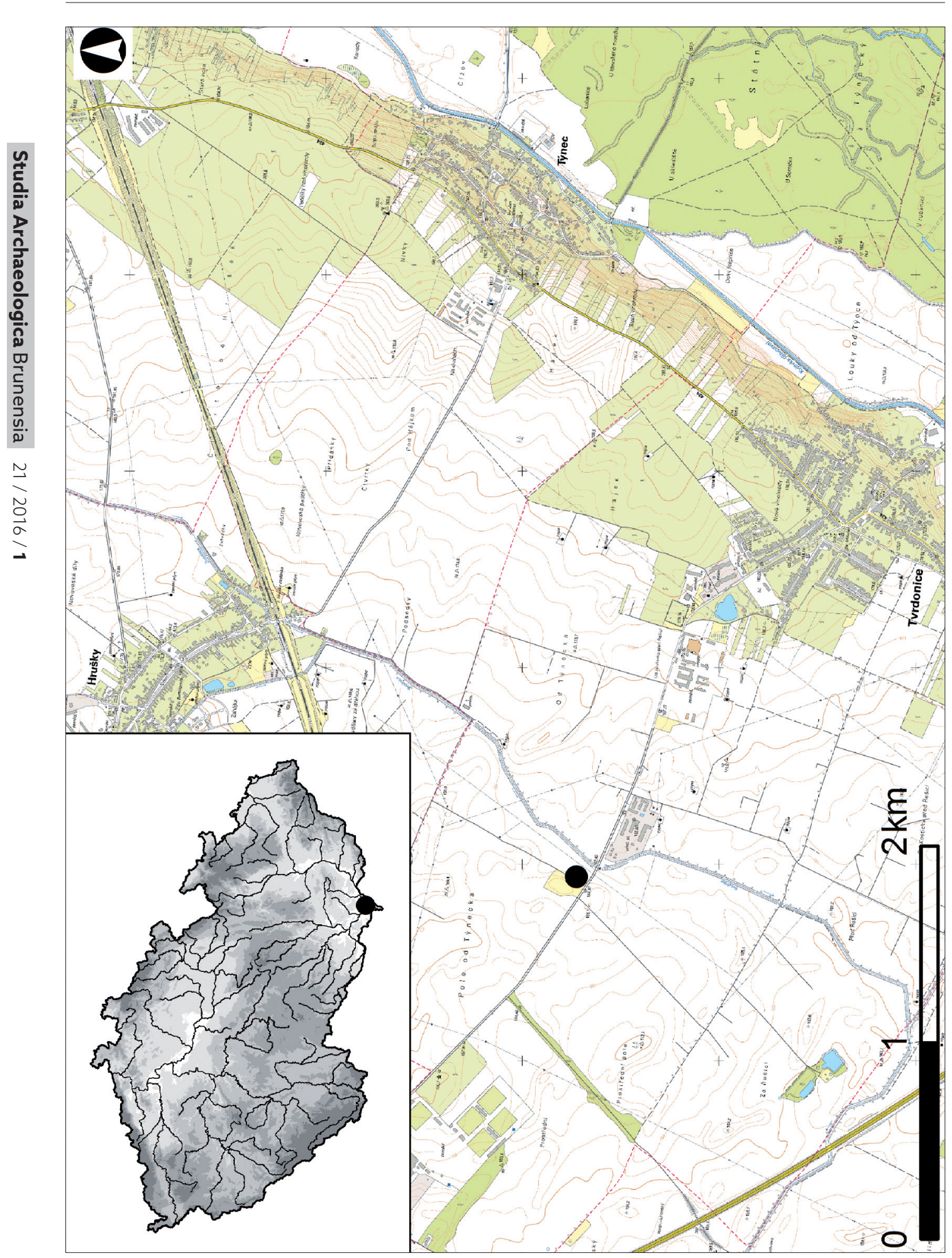




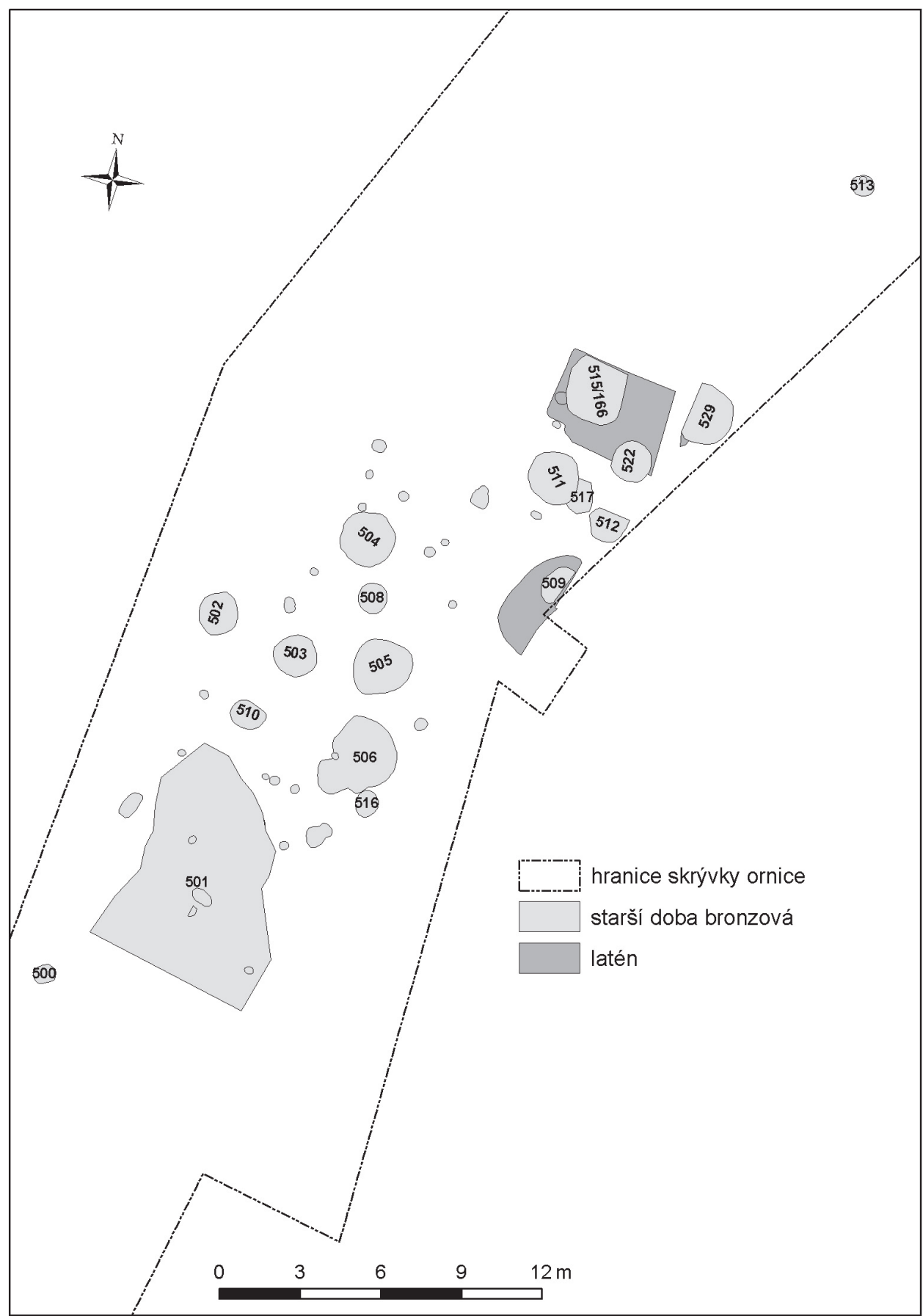

Obr. 2. Celkový plán odkryté plochy Tvrdonice - Pole od Týnecka 2012.

Fig. 2. General plan of the excavation area Tvrdonice - Pole od Týnecka 2012. 


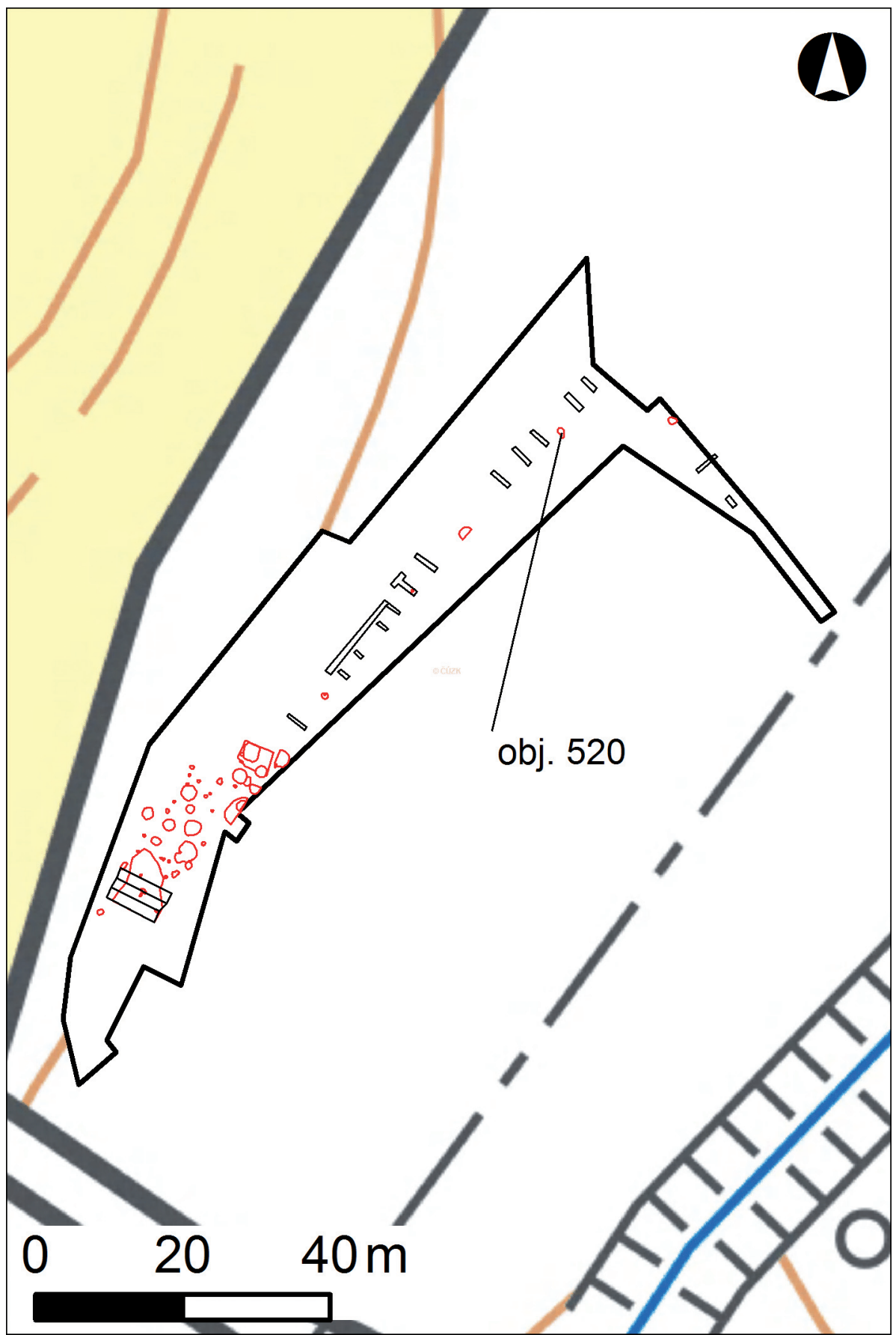

Obr. 3. Distribuce věteřovských artefaktů na lokalitě Tvrdonice - Pole od Týnecka.

Fig. 3. Distribution of Věteřov artefacts at the Tvrdonice - Pole od Týnecka site. 
známých artefaktů. Na základě jednoho souboru dané velikosti ani nepovažujeme za nutné znovu porovnávat charakter ŠI ze sídlišt a pohřebišt, již jen proto, že moderně dokumentovaných souborů z pohřebišt je zatím málo, a proto by se podobná analýza neměla mnoho o co opírat. Z nedávnějších studií je, kromě skromného příspěvku k mužským atributům v ŠI (Kaňáková - Parma 2015) a výše zmíněných monografických přehledů pro Moravu, vhodné zmínit nedávno obhájenou diplomovou práci T. Rychtaříkové (2013), která přináší první zásadní vhled do charakteru ŠI starší doby bronzové na území dnešních Čech. Dlužno ovšem zmínit, že jak surovinově, typologicky i z hlediska tradic a sociálních vzorců se jeví tato oblast významně odlišná od moravské.

\section{Analýza}

Soubor 33 artefaktů kromě typologicky tříditelných artefaktů zahrnuje dva valounové otloukače z rohovce typu Krumlovský les I (dále jen KL I) a tři zlomky suroviny (křemenec, KL II a neurčený přepálený fragment) s několika záměrnými negativy. Detailněji lze tedy zhodnotit 29 artefaktů, z toho 16 nástrojů a jediné jádro.

Surovinově je soubor poměrně homogenní, téměř výhradně orientovaný na zdroje surovin v Krumlovském lese, což odpovídá dosavadnímu poznání. Rohovec typu Krumlovský les I (dále KL I) tvoří 72,73 \% souboru, varieta rohovec typu Krumlovský les II (dále KL II) pak 15,15\%. Surovinové spektrum doplňují izolované výskyty křemene, křemence z oblasti Krumlovského lesa a neurčené (přepálené) suroviny (od každé 1 ks). Rohovcová brekcie se nevyskytla.

Zastoupení jemných hmot je v porovnání s dosud pozorovanou situací (Kaňáková 2013, 34) výraznější, a to nejen v rámci výskytu rohovce KL II, pro nějž je typická. Zatím byla ve starší době bronzové na jižní Moravě konstato- vána spíše preference hmot kvalitních ${ }^{3}$, rezistentnějších $\mathrm{k}$ opotřebení. Anomálie byla zatím sledována pouze ve výběru surovin tzv. mikrojader, kde zřejmě jemnější surovina hrála roli v úspěšnosti minuciózní těžby jádra, jakož i v estetizující atraktivitě procesu i produktů (Kaňáková 2014, 17-18). Jemné hmoty tvoří více než čtvrtinu souboru (29,03\%), i když velikost souboru samozřejmě výsledek statisticky relativizuje. Ucelenější informaci o spektru hmot podle tzv. škály kvality poskytuje Obr. 4A. V případě Tvrdonic nelze konstatovat nějaký jasně patrný motiv této preference jemných hmot $\mathrm{u}$ variety KL I. Nejsou vyhrazeny retušovaným nástrojům, ve výběru jsou různé typy neopotřebené a neretušované debitáže (2 nekortikální a 1 semikortikální úštěp) a místně retušovaný úštěp bez funkční specifikace. Naopak v př́ípadě KL II je motivace preference homogenní suroviny nápadnější - z pěti artefaktů z KL II jsou tři retušované nástroje a jedno mikrojádro. $\mathrm{V}$ jednom případě je ovšem hmota KL II hodnocena jako kvalitní a nikoli jemná. Nástroje z jemné $(2 \times \mathrm{KL}$ II), případně jemné/kvalitní hmoty $(1 \times \mathrm{KL}$ I) jsou překvapivě dlátka a vrub, tedy třídy považované spíše za nástroje hrubší (alespoň v kontextu starší doby bronzové). Poměr jemných hmot u nástrojů není tak výrazný.

Z hlediska hodnocení suroviny je dále nápadné relativně vysoké procento přepálených artefaktů. Celkem 9 přepálených artefaktů (27,3\% souboru) je až na jednu výjimku z rohovce KL I. Výjimku tvoří jen již výše zmíněný fragment neurčitelné suroviny. Pomineme-li tento nález, jehož surovina je jemná, vždy se u přepálených artefaktů z Tvrdonic jedná o suroviny kvalitní hmoty. Z hlediska typologie netvoří homogenní skupinu, jsou zastoupeny typy neretušované debitáže, místně retušovaný úštěp i retušované nástroje. Mezi nimi je zlomený srpový nástroj a dále dvě pilky s bifaciálně retušovaným ostřím a bokem. Sledované znaky na štípané industrii mají výraznou prostorovou vazbu pouze 

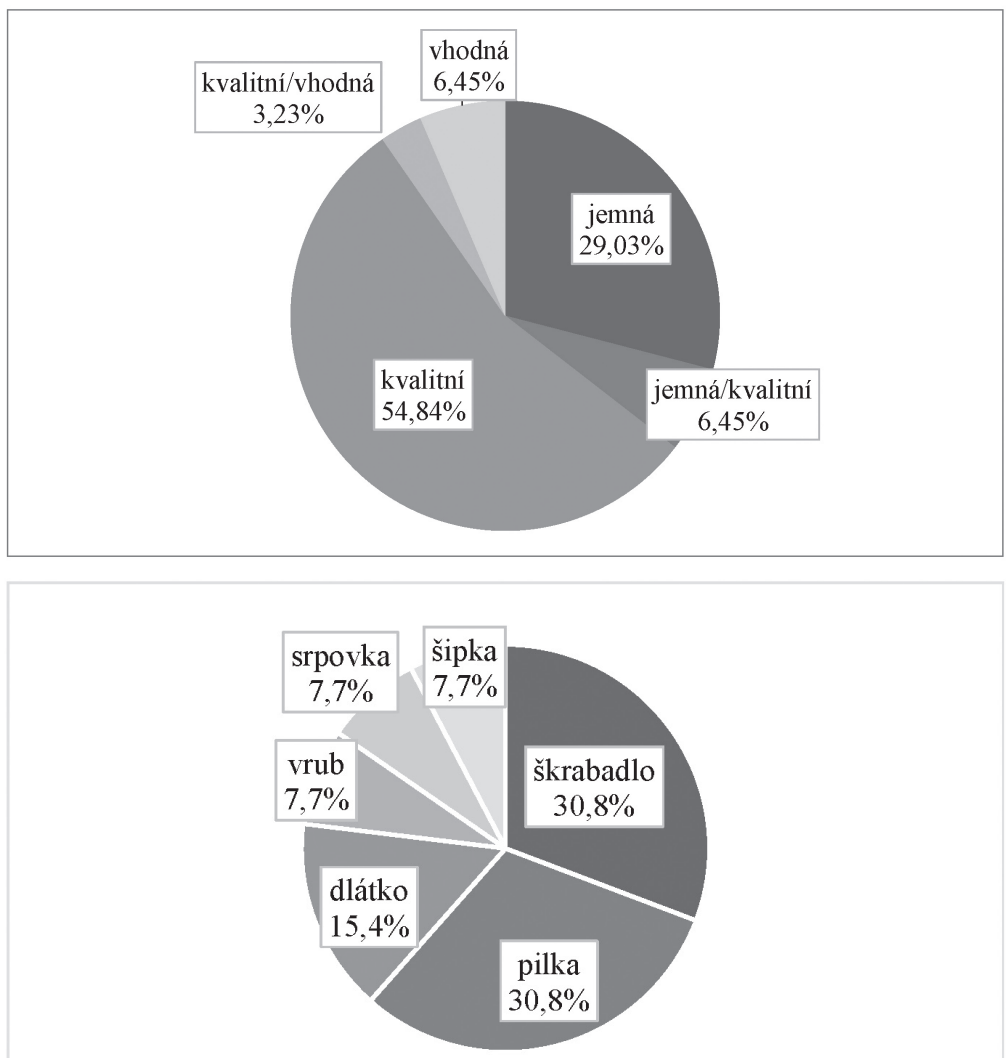

Obr. 4. A - graf spektrum kvality hmoty

B - graf typologické spektrum Šl z lokality Tvrdonice - Pole od Týnecka.

Fig. 4. A - graph of spectrum of mass quality

B - graph of typological spectrum of chipped stone industry from the Tvrdonice - Pole od Týnecka site.

na kumulaci zásobních jam s velkým počtem nálezů všech kategorií hmotné kultury. V objektech s nálezy nebyly zjištěny stopy žáru; lze pouze konstatovat, že malá část fragmentů zvířecích kostí a schránek velevruba byla rovněž přepálena. Z toho lze soudit, že tyto nálezy byly přepáleny před skartací a depozicí v sídlištních jamách (at̉ již akcidentálně nebo záměrně).

Dynamická analýza prezentuje sídliště z hlediska distribuce ŠI jako plně zásobené zvenčí, bez místních výrobních elementů. Distribuce je výhradně zajištěna z oblasti Krumlovského lesa a to pravděpodobně minimálně na úrovni debitáže připravené $\mathrm{k}$ použití nebo $\mathrm{k}$ případné retuši. Vysoký podíl kortikální a semikortikální debitáže v souboru bez jader a odpadu odpovídá dosud zjištěným preferencím tohoto distribučního okruhu starší doby bronzové na jižní Moravě (Kaňáková 2013, 40-41), který ve značném podílu distribuuje i tuto tzv. sekundární debitáž. Otázka rozlišení produkce na tzv. cílové produkty (nekortikální, jistým způsobem standardizovaná debitáž) a vedlejší produkty (produkty dekortikace, preparace a reparace) ve starší době bronzové není relevantní. Úštěpy 
s kůrou, úštěpy s výraznými hřbety a útvary na dorzální ploše (často reparační úštěpy), a úštěpy s bokem nebo boky jsou oblíbenými suporty pro výrobu nástrojů (místně retušovaná debitáž a retušované nástroje) nebo pro přímé použití (opotřebená debitáž s definovanou funkcí). Podrobnější přehled o využití jednotlivých typů produktů exploatace jádra na sídlišti Tvrdonice - Pole od Týnecka přináší Tab. 1. Jak je patrné, kortikální a semikortikální úštěpy jsou jen minimálně ponechávány neretušované a vyskytují se především v kategorii retušovaných nástrojů (pilky, škrabadla, dlátko). Naproti tomu tzv. cílová nekortikální debitáž (úštěpy bez kưry a bifaciální debitáž typu janus) je využita k výrobě nástroje jen v $50 \%$. Rovněž zde převažují retušované nástroje (39,4 \% souboru), zatímco opotřebená a místně retušovaná debitáž je v menšině. Převažuje tedy tendence $\mathrm{k}$ užívání standardizovaných retušovaných morfotypů, především pilek a škrabadel.

Zjištěné mikrojádro zcela odpovídá obvyklým parametrům této speciální skupiny štípaných artefaktů. Produkty jeho exploatace nebyly na lokalitě zjištěny, sediment nicméně nebyl s ohledem na podmínky záchranného výzkumu plaven. Charakterizuje je pravidelná úštěpová těžba objemového konceptu z jedné podstavy, s náznakem zřejmě ploché boční úpravy. Vzhledem k nepřítomnosti běžných jader, odpadu a dalších dokladů výroby, nelze dva zjištěné valouny z KL I chápat jako doklady výroby štípané industrie na sídlišti. Mohly být použity jako otloukače nebo drtiče, nikoli však k místní výrobě ŠI, pokud můžeme soudit $\mathrm{z}$ analyzovaného souboru.

Přejdeme-li k posouzení typologického spektra souboru (Obr. 4B), pak v něm ve srovnání s jinými sídlišti nápadně chybí jeden z nejtypičtějších nástrojů starší doby bronzové - kamenný nůž s neretušovaným ostř́ím a s bokem. Nástroje funkční skupiny longitudálních ostří pro dělení měkké hmoty jsou zastoupeny pouze pilkami a jedinou zlomenou a přepálenou srpovkou. Druhá část skartovaného nástroje chybí, jak je na sídlištích únětické kultury časté (Kaňáková 2014, 22-23). Zatímco vyšší zastoupení pilek nijak nevyčnívá, počet škrabadel je nápadnější. Jistě, je třeba vzít v úvahu, že soubor je příliš malý na závažnější statistické závěry, přesto při dosavadním zjištěném počtu škrabadel z únětických sídlišt na Moravě (29 ks) jsou čtyři na jediném sídlišti poměrně velký soubor. Pochází pouze z únětických objektů lokality Tvrdonice. Celkový přehled únětických sídlišt na Moravě se škrabadly, který vychází z aktualizovaných dat poslední syntézy (Kaňáková 2013, 128-129 a 230) uvádí Tab. 2. Naše možnosti analýzy poněkud relativizuje fakt, že u některých sídlišt nebylo u části objektů možné přesnější zařazení

\begin{tabular}{|l|c|c|c|c|}
\hline \multicolumn{1}{|c|}{$\begin{array}{c}\text { stádium } \\
\text { exploatace }\end{array}$} & neretušované & opotřebené & $\begin{array}{c}\text { místně } \\
\text { retušované }\end{array}$ & $\begin{array}{c}\text { retušované } \\
\text { nástroje }\end{array}$ \\
\hline kortikální úštěp & 1 & & 1 & 2 \\
\hline semikortikální úštěp & 2 & 1 (dlátko) & 1 & 7 \\
\hline úštěp bez kưry & 7 & & & 13 \\
\hline janus úštěp bez kưry & 1 & & 2 & $\mathrm{n}$ \\
\hline artif. zlomky suroviny & 3 & 1 & $\mathrm{n}$ & \\
\hline celkem & 13 & 1 & & \\
\hline jádro & & & & \\
\hline
\end{tabular}

Tab. 1. Dynamická analýza souboru Šl z lokality Tvrdonice - Pole od Týnecka.

Tab. 1. Dynamic analysis of an assemblage of chipped stone industry from the Tvrdonice - Pole od Týnecka site. 
v rámci starší doby bronzové (Blučina - Cezavy), na některých se vyskytly objekty jak kultury únětické, tak věteřovské (Velké Pavlovice - Nad zahrady, Olbramovice - obchvat), a některá byla pouze sbírána, takže hypoteticky mohou skrývat intruze, jejichž př́tomnost nemusela z povrchových nálezů vyplynout. Tak můžeme konstatovat, že nejvíce škrabadel starší doby bronzové pochází na Moravě z Blučiny - Cezav; složitá kulturní a stratigrafická situace polohy však neumožňuje chápat tamní škrabadla spolehlivě jako celek. Jak je patrné, existují jen další dvě sídliště, odkud pochází více škrabadel (Hostěradice IA, Hrádek I - Vinohrad), oba soubory pochází však z povrchových sběrů. Ve světle dosavadních poznatků se tak Tvrdonice jeví jako sídliště s dosud největším zjištěným spolehlivě únětickým souborem škrabadel.

Škrabadla z Tvrdonic, podobně jako škrabadla starší doby bronzové na Moravě obecně, nejsou nijak standardizovaným nástrojem. Vyskytne se výrazné škrabadlo na boku s opozitním ventrálně upraveným kortikálním bokem (Obr. 5/6), stejně jako škrabadlová laterální úprava bez opozitního boku (Obr. 5/20), dvojité škrabadlo na podélném - avšak kortikálním - úštěpu (Obr. 5/16), i miniaturní škrabadélko, zjevně reparované na zlomeném kusu (Obr. 5/23). Pro tuto nesourodost byla všechna škrabadla podrobena traseologické analýze, s cílem potvrdit nebo vyloučit jejich použití na tradičně předpokládané zpracování kůže. Škrabadla se nekumulovala v konkrétním objektu, a pokud bychom zvažovali jakousi funkční zónu na základě prostorové blízkosti objektů 503, 506 a 508, ve zjištěném počtu škrabadel je naprosto nevýrazná a tedy neprůkazná. Protože kožedělná funkce byla již dříve konstatována také u kamenných pilek starší doby bronzové na Moravě (Kaňáková 2013, 193-194), byly rovněž

\begin{tabular}{|c|c|c|c|}
\hline únětická sídliště & poznámka & určení suroviny & počet škrabadel \\
\hline Čejč - Kapánsko & sběr & MJR & 1 \\
\hline Svatobořice-Mistřín - Písky II & sběr & MJR & 2 \\
\hline Hrádek I - Vinohrad & sbĕr & KLI & 4 \\
\hline Vyškov - Markova cihelna & & $\overline{K L I}$ & 2 \\
\hline Olbramovice obchvat 2003 & & $\mathrm{KL} \mathrm{I/KL} \mathrm{II}$ & 1 \\
\hline Blučina Cezavy & & $\mathrm{KLI}$ & 1 \\
\hline Hostěradice I A Milan Vokáč sběr & sběr & KLI & 4 \\
\hline Velké Pavlovice - Nad zahrady & & $2 \times K L I, 1 \times K L \|$ & 3 \\
\hline Brno Černá pole - dětská nemocnice & & $\mathrm{KL}$ I & 1 \\
\hline Podolí III & & KLI & 1 \\
\hline Hrušovany nad Jevišovkou - sever & & $1 \times K L I, 1 \times K L I I$ & 2 \\
\hline Brno - Výstavní ulice & & $\mathrm{KL} \|$ & 1 \\
\hline Podolí - Př́čný & & StrS & 2 \\
\hline Trrdonice - pole od Týnecka & & $3 \times K L I, 1 \times K L \|$ & 4 \\
\hline \multicolumn{3}{|l|}{ celkem } & 29 \\
\hline
\end{tabular}

Tab. 2. Přehled dosud známých škrabadel ze z únětických sídlišt' na Moravě. KL I a II - rohovec typu Krumlovský les I a II, StrS - rohovec typu Stránská skála, MJR - moravský jurský rohovec.

Tab. 2. An overview of hitherto known end-scrapers from settlements of Únětice Culture in Moravia. KL I and II - Krumlovský les chert I and II, StrS - Stránská skála chert, MJR - Moravian Jurassic chert. 

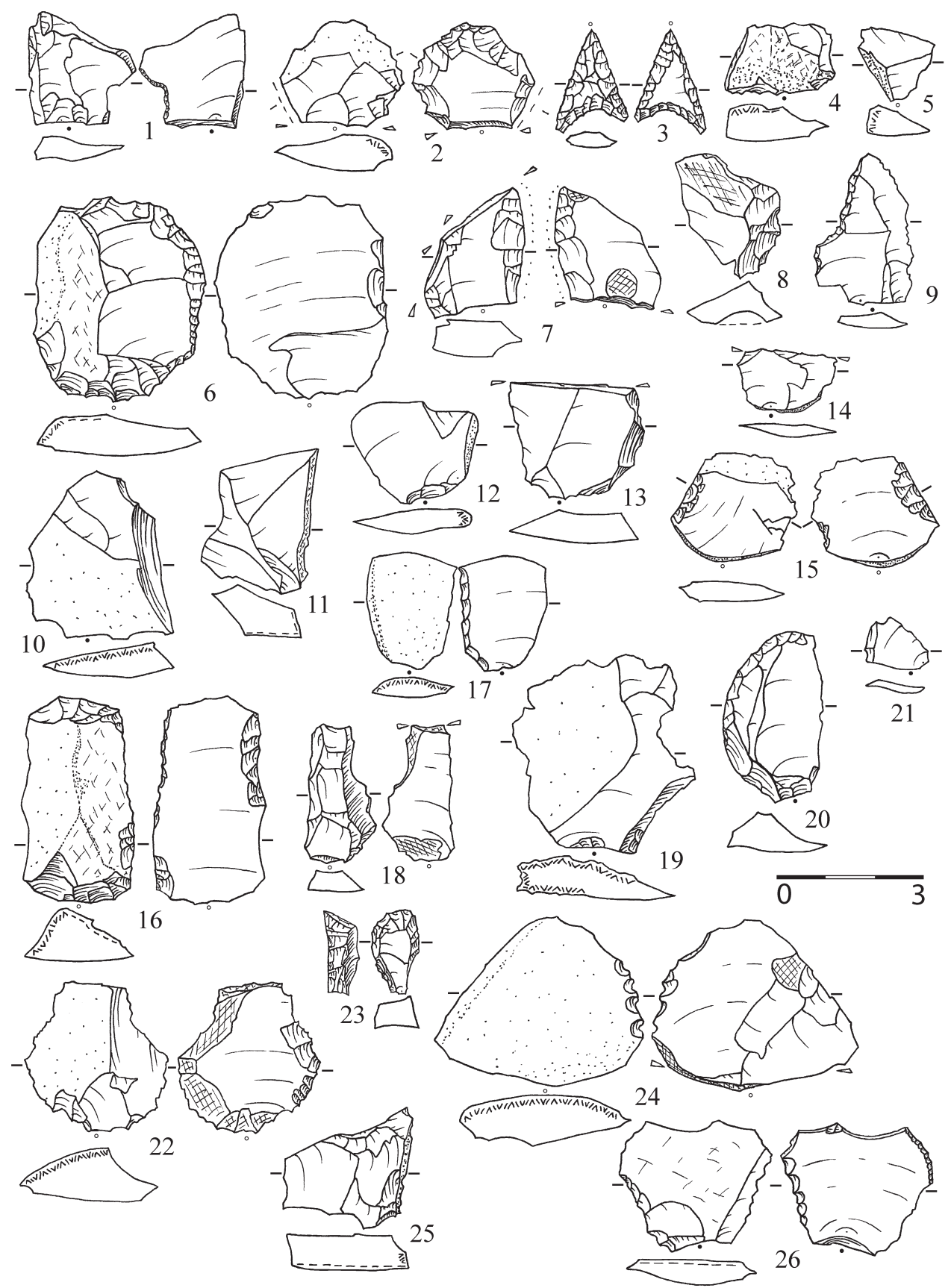

Obr. 5. Tvrdonice - Pole od Týnecka: štípaná industrie z únětických zásobních jam v JV části plochy výzkumu.

Fig. 5. Tvrdonice - Pole od Týnecka: chipped stone industry from storage pits of Únětice Culture in the SE part of the excavation area. 

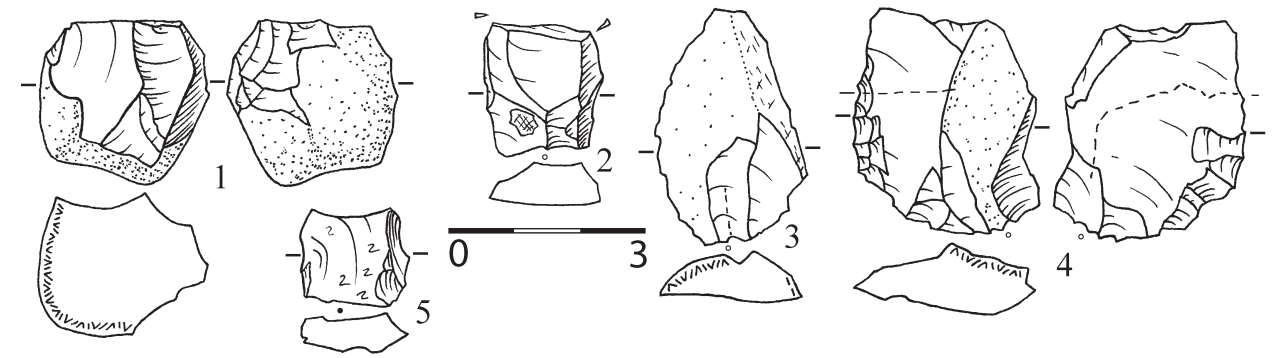

Obr. 6. Tvrdonice - Pole od Týnecka: štípaná industrie z objektu 520 a sond v SZ části plochy výzkumu.

Fig. 6. Tvrdonice - Pole od Týnecka: chipped stone industry from Feature 520 and from excavation trenches in the NW part of the excavation area.

pilky z Tvrdonic posouzeny pod mikroskopem. Ani pilky se nikdy nevyskytly v jednom objektu vícekrát, a sešly se jen v jednom př́ípadě se škrabadly (obj. 506). Existenci funkční zóny tedy nemůžeme přes neobvyklý počet škrabadel předpokládat. Traseologické posouzení bylo provedeno na mikroskopu BX51M Olympus, při zvětšení 200×. Traseologické výsledky v př́ipadě pilek neprríznivě ovlivnilo přepálení obou bifaciálně retušovaných exemplářů, které možnosti této metody na silicitových surovinách limituje. Jedna z unifaciálních pilek byla vyrobena $\mathrm{z}$ poměrně hrubozrnné suroviny, na níž žádné traseologicky identifikovatelné stopy nebyly čitelné. Pouze na poslední z pilek (obj. 515) byly zjištěny vágní stopy ohlazení zoubků pracovní hrany. V případě škrabadel bylo markantní opotřebení transverzálním opracováním kůží (ohlazení okraje hrany a striace kolmé na tuto pracovní hranu) pozorováno na ventrální ploše obou pracovních hlavic dvojitého škrabadla z objektu 506 (Obr. 7). Na povrchu pracovních hran škrabadel z objektů 503 a 508 nebylo opotřebení tak výrazně vyvinuté, ale svědčí pro stejnou funkci. Naproti tomu miniaturní reparované škrabadélko z objektu 513 nevykazovalo žádné stopy opotřebení následující po etapě přeretušování na zlomeném kusu. Z provedené analýzy tedy můžeme konstatovat, že ačkoli vzhledem k celkovému počtu škrabadel na sídlištích starší doby bronzové musíme předpokládat zpracování kůží primárně jinými nástroji, resp. nástroji z jiných než kamenných surovin, zjištěná kamenná škrabadla byla takto dosud rovněž používána.

Poslední významnou položkou typologického spektra lokality je kamenný projektil - šipka z objektu 502, rovněž nález na sídlištích starší doby bronzové na Moravě poměrně vzácný. $\mathrm{Z}$ únětického kontextu jich známe včetně této pouhých 10 ks (Tab. 3), a to dvě pochází opět z povrchových sběrů a jedna z nerozlišeného inventáře sídliště a pohřebiště ve Vrbovci, nemusí jít tedy o nález ze sídliště. Můžeme tedy konstatovat, že lukostřelba na únětických sídlištích bud' nepatřila k běžným aktivitám, anebo byly projektily vyřazovány mimo jejich areál přímo po použití. Na základě dosavadního poznání inventáře starší doby bronzové na Moravě můžeme vyloučit používání jiných materiálů, jak bronzu, tak kosti, užívaných pro tento účel v mladších obdobích. Traseologická analýza projektilu z Tvrdonic ukázala jasné opotřebení způsobené upevněním do násady jak v prostoru vkleslé báze, tak na obou křidélkách (Obr. 8). Horní polovina projektilu je však zcela bez opotřebení a hrot nepostihuje funkční ani jiná fraktura. Můžeme tedy konstatovat, že hrot byl at 


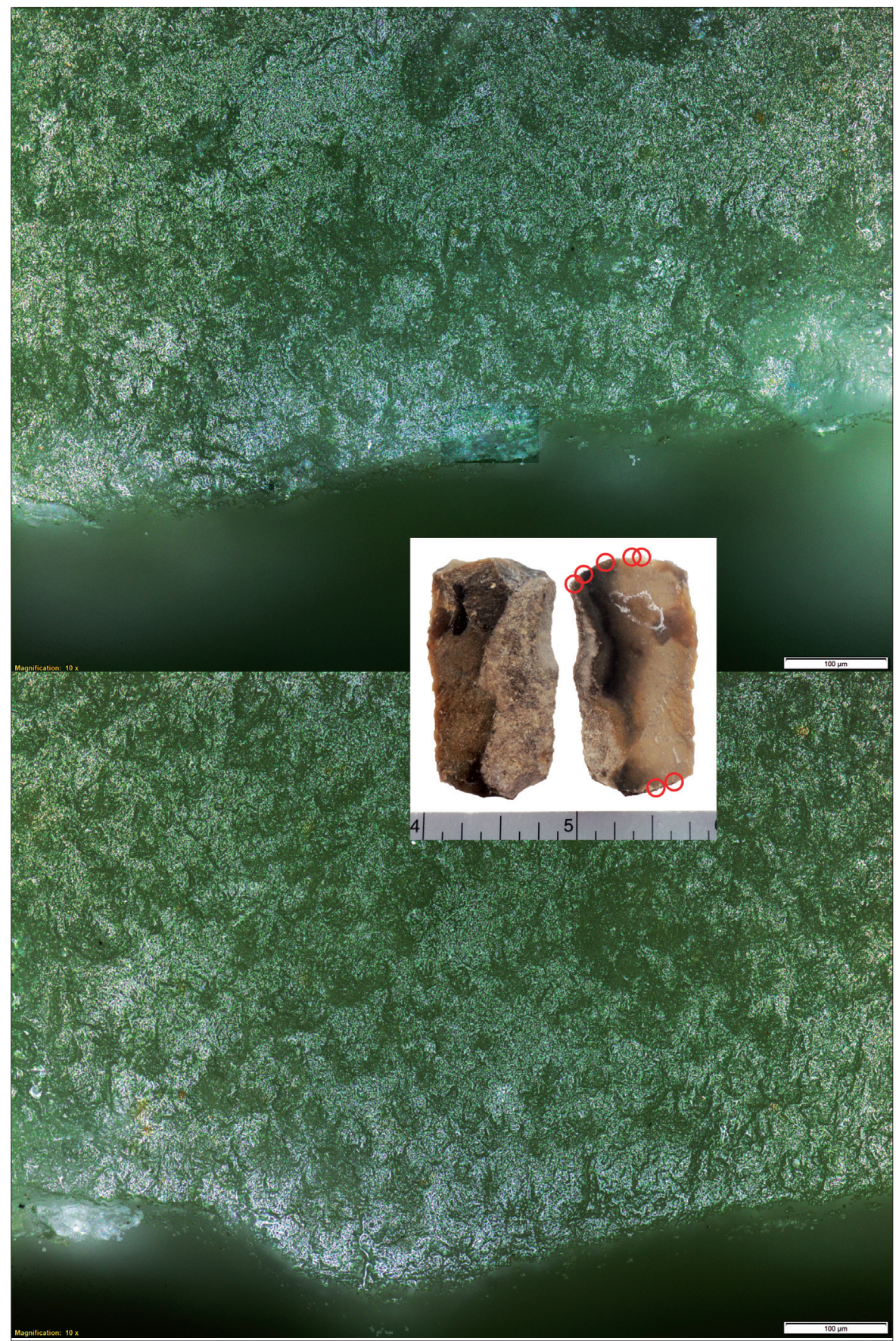

Obr. 7. Mikrosnímky a lokalizace zjištěných opotřebení pracovních hran dvojitého škrabadla z objektu 506.

Fig. 7. Photomicrographs and localisation of use-wear marks on working edges of a double end-scraper from Feature 506. 

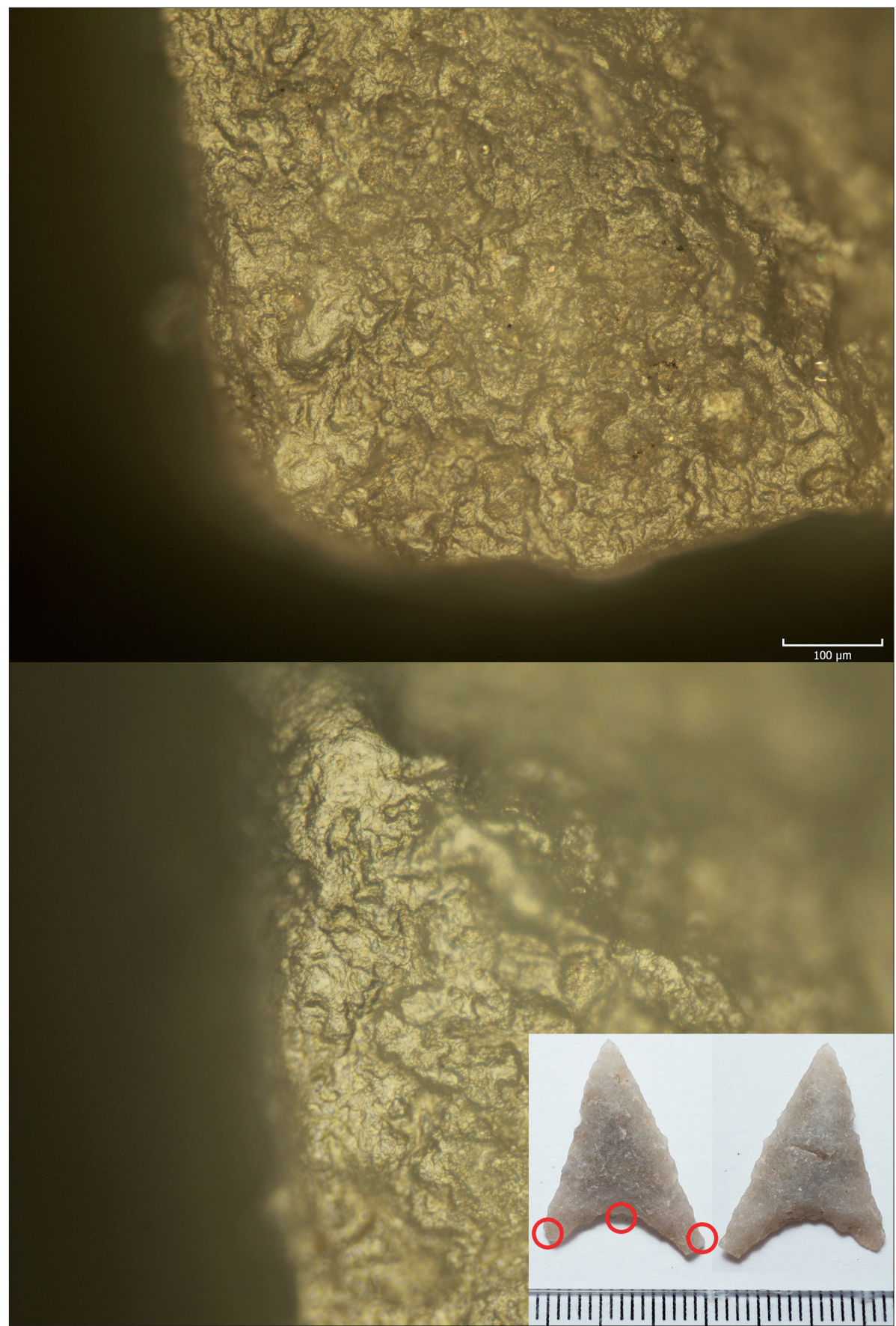

Obr. 8. Mikrosnímky lokalizace zjištěných opotřebení projektilu - šipky z objektu 502.

Fig. 8. Photomicrographs and localisation of use-wear marks on a projectile - arrowhead from Feature 502. 


\begin{tabular}{|c|c|c|c|}
\hline únětická sídliště & poznámka & určení suroviny & počet \\
\hline Brno-Černá pole - dětská nemocnice & & $1 \times K L I, 1 \times M J R$ & 2 \\
\hline Hostěradice IA & sběr & KLI & 1 \\
\hline Hrádek I - Vinohrad & sběr & KL II & 1 \\
\hline Křižanovice/Marefy - Člupy & & $\mathrm{KLI}$ & 1 \\
\hline Šatov - Nad tokem Danýže & & $\mathrm{KLI}$ & 1 \\
\hline Těšetice/Dobšice - Guttwillingerova cihelna & & KLI & 1 \\
\hline Troubsko - za kostelem & & KLI & 1 \\
\hline Tvrdonice - pole od Týnecka & & KLI & 1 \\
\hline Vrbovec - Langova cihelna & směs & $\mathrm{KLI}$ & 1 \\
\hline \multicolumn{3}{|l|}{ celkem } & 10 \\
\hline
\end{tabular}

Tab. 3. Přehled dosud známých kamenných šipek z únětických sídlišt' na Moravě.

Tab. 3. An overview of hitherto known lithic arrowheads from settlements of Únětice Culture in Moravia.

záměrně či náhodně deponován v zásobní jámě ve stavu připraveném k použití, nejde nicméně o hrot nepoužitý, nový či pouze symbolický artefakt. Tento hrot byl upevněn v ratišti šípu na tak dlouhou dobu, že se na poměrně značně rezistentní surovině rohovce typu KL I vytvořily markantní otěry a striace. Je pravděpodobné, že jde o hrot čerstvě po reparaci fraktury hrotu, kdy báze zůstává beze změny (a uchovává tedy již získaná opotřebení), zatímco hrot a část laterálních hran jsou čerstvě přeretušovány.

\section{Závěry}

Analýza štípané industrie ze sídlišt doplňuje naše informace o aktivitách, které na nich probíhaly, informuje nás o způsobu distribuce kamenných surovin a vůbec o nakládání s nimi, o technikách jejich zpracování a spektru činností, k nimž byly artefakty (ne vždy jen nástroje) z nich vyrobené používány, jaké materiály se jimi opracovávaly a jakým způsobem byly vyřazovány z používání. I drobnější soubory si zaslouží maximální exploataci archeologických dat, které přináší. Soubor ze sídliště Tvrdonice Pole od Týnecka v řadě svých projevů potvrzuje hlavní charakteristiky ŠI starší doby bronzové, především ve volbě zdroje kamenných surovin v Krumlovském lese, charakteru distribuovaných produktů s významným podílem debitáže s kůrou a oblibou janus debitáže, nebo vysokém podílu nástrojů a minimu dokladů výroby ŠI na sídlištích. Musíme však konstatovat ne zcela obvyklé typologické spektrum s výraznějším podílem škrabadel, bez přítomnosti nožů a jen s jediným srpovým nástrojem. Také zjišstěný projektil se řadí k dosud nepočetným nálezům tohoto druhu z moravských sídlišt starší doby bronzové. S ohledem na velikost souboru z těchto výsledků nevyvozujeme žádné závažné závěry o výjimečnosti zkoumaného sídliště. Existenci ohraničené funkční zóny zaměřené na zpracování kůží nelze prokázat.

\section{Poznámky:}

1) Dále byly zjištěny 2 zlomky suroviny (rohovec typu Krumlovský les I) beze známek artificiality.

2) O tom podrobněji na jiných místech - zvl. Kaňáková 2014, 7-11 aj.

3) Škála kvality suroviny je používána autorkou od začátku jejího výzkumu ŠI mladšího pravěku, tedy asi od roku 2000 (Hladíková 2004, 69; Kaňáková 2013, 20) 


\section{Literatura}

Hladíková, L. 2004: Štípaná industrie starší doby bronzové, Sborník prací Filozofické fakulty brněnské univerzity, řada M 8-9, 65-87.

Kaňáková, L. 2013: Posteneolitická štípaná industrie na Moravě. Brno.

Kaňáková, L. 2014: Unikátní soubor štípané industrie doby bronzové z polohy Blučina - Cezavy, Památky archeologické CV, 5-46.

Kaňáková, L. - Parma, D., 2015: Štípaná industrie z pohřebiště únětické kultury v poloze Podolí Příčný (okr. Brno-venkov) jako indikátor sociálních jevů, Archeologické rozhledy LXVII, 515-546.

Rychtaříková, T. 2013 (rkp.): Štípaná kamenná industrie v kontextu starší doby bronzové. Diplomo-

\section{Resume}

The assemblage of chipped stone industry was obtained during excavation of an Early Bronze Age settlement site at Trrdonice - Pole od Týnecka. Chipped stone industry was found in settlement features (storage pits) of Únětice and Věteřov cultures. The assemblage comprises 33 artefacts and is homogeneous as regards the raw materials used. All raw materials probably come from the area of Krumlovský les. The Krumlovský les I chert represents $73 \%$, Krumlovský les II chert $15 \%$. Chert breccia, which usually also occurs with Early Bronze Age assemblages of chipped stone industry in Moravia, is not present. The assemblage is characterised by a high proportion of tools (41\%), only a single core, and exclusively flake debitage. Most tools can be classed with defined typological groups, that is as retouched tools. The number of worn and locally retouched tools is negligible. Tools are made on non-cortical vá práce Karlova univerzita, Filozofická fakulta, Ústav pro archeologii, Praha.

Kopacz, J. - Šebela, L. 2006: Kultura unietycka i grupa wieterzowska na Morawach na podstawie materiałów krzemieniarskich. Kraków.

Trampota, F. 2013: Tvrdonice, Přehled výzkumů 54/1, 192-193.

Unger, J. 1973: Nové nálezy ze štěrkovny u Tvrdonic (okr. Břeclav), Přehled výzkumů 1972, 26.

Unger, J. 1975: Nové nálezy z pískovny u Tvrdonic (okr. Břeclav), Přehled výzkumů 1974, 95.

Všianský, D. - Kolář, J. - Petř́ík, J. 2014: Continuity and changes of manufacturing traditions of Bell Beaker and Bronze Age encrusted pottery in the Morava river catchment (Czech Republic), Journal of Archeological Science 49, 414-422.

flakes (so-called final debitage) rather than on cortical flakes. The typological spectrum corresponds to the Early Bronze Age, even though the representation of individual groups is unusual. The assemblage is dominated by endscrapers and saws, knives are not present at all, and sickle tools are represented by only a single specimen. End-scrapers and saws have been used for skin processing but they do not form any conclusive accumulation or functional zone within the settlement. End-scrapers are very variable as regards their morphology. The assemblage also contains an arrowhead with attested use wear at the base and barbs, but not at the tip where the edges of scars are sharp. So, it can be concluded that the arrowhead has not been used (hafted on a shaft) for a long time, but the point was probably sharpened or rejuvenated after breakage shortly before being deposited in the feature. 
Mgr. Ludmila Hladíková-Kaňáková, Ph.D.

- Ústav archeologie a muzeologie, Filozofická fakulta, Masarykova univerzita, Arna Nováka 1, 60200 Brno
Mgr. František Trampota, Ph.D.

- Regionální muzeum v Mikulově Zámek 22/1, CZ 69201 Mikulov 